\author{
DEPARTMENT OF THE INTERIOR \\ UNITED STATES GEOLOGICAL SURVEY
}

PREPARED IN COOPERATION WITH

THE MICHIGAN DEPARTMENT OF CONSERVATION

GEOLOGICAL SURVEY DIVISION

\title{
AEROMAGNETIC MAP OF PART OF THE BEECHWOOD QUADRANGLE, MICHIGAN AND WISCONSIN
}

GEOPHYSICAL INVESTIGATIONS

MAP GP-603

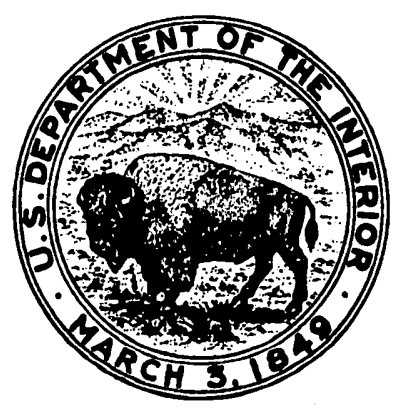

